\title{
Effectiveness and Efficacy of Vaccine on Mutated SARS-CoV-2 Virus and Post Vaccination Surveillance: A Narrative Review
}

\author{
Ihsanul Hafiz ${ }^{1,2,+}\left(\mathbb{D}\right.$, Didi Nurhadi Illian ${ }^{3,+}+\mathbb{D}$, Okpri Meila ${ }^{3,4}$, Ahmad Rusdan Handoyo Utomo ${ }^{5}$, \\ Arida Susilowati ${ }^{6,7}$, Ipanna Enggar Susetya ${ }^{6,8}$, Desrita Desrita ${ }^{6,8}$, Gontar Alamsyah Siregar 6,9 \\ and Mohammad Basyuni ${ }^{6,7, * \text { (D) }}$
}

check for updates

Citation: Hafiz, I.; Illian, D.N.; Meila, O.; Utomo, A.R.H.; Susilowati, A.; Susetya, I.E.; Desrita, D.; Siregar, G.A.; Basyuni, M. Effectiveness and Efficacy of Vaccine on Mutated SARS-CoV-2 Virus and Post Vaccination Surveillance: A Narrative Review. Vaccines 2022, 10, 82. https://doi.org/10.3390/ vaccines 10010082

Academic Editors: Soo-Hong Lee, Hansoo Park, Jagathesh Chandra Rajendran and K. S. Jaganathan

Received: 4 November 2021

Accepted: 4 January 2022

Published: 6 January 2022

Publisher's Note: MDPI stays neutral with regard to jurisdictional claims in published maps and institutional affiliations.

Copyright: (C) 2022 by the authors. Licensee MDPI, Basel, Switzerland. This article is an open access article distributed under the terms and conditions of the Creative Commons Attribution (CC BY) license (https:// creativecommons.org/licenses/by/ $4.0 /)$.
1 Department of Pharmacology, Faculty of Pharmacy and Health, Institut Kesehatan Helvetia, Medan 20124, Indonesia; ihsanulhafiz@helvetia.ac.id

2 Doctoral Program in Pharmacy, Department of Pharmaceutical Biology, School of Pharmacy, Institut Teknologi Bandung, Bandung 40132, Indonesia

3 Department of Pharmacy, Faculty of Mathematics and Natural Sciences, Universitas Syiah Kuala, Banda Aceh 23111, Indonesia; illian.didinurhadi@unsyiah.ac.id (D.N.I.); okprimeila@unsyiah.ac.id (O.M.)

4 Doctoral Program of Clinical Pharmacy and Pharmacology, Faculty of Pharmacy, Universitas Indonesia, Depok 16424, Indonesia

5 Faculty of Medicine, Universitas YARSI, Jakarta 10510, Indonesia; ahmad.rusdan@yarsi.ac.id

6 Center of Excellence for Mangrove, Universitas Sumatera Utara, Medan 20155, Indonesia; arida.susilowati@usu.ac.id (A.S.); ipannaenggar@gmail.com (I.E.S.); desrita@usu.ac.id (D.D.); gontar@usu.ac.id (G.A.S.)

7 Department of Forestry, Faculty of Forestry, Universitas Sumatera Utara, Medan 20155, Indonesia

8 Department of Aquatic Resource Management, Faculty of Agriculture, Universitas Sumatera Utara, Medan 20155, Indonesia

9 Division of Gastroenterology-Hepatology, Department of Internal Medicine, Faculty of Medicine, Universitas Sumatera Utara, Medan 20155, Indonesia

* Correspondence: m.basyuni@usu.ac.id; Tel.: +62-61-8201920

+ These authors contributed equally to this work.

\begin{abstract}
The ongoing COVID-19 pandemic, as a result of the SARS-CoV-2 virus, since December 2019, is a major health problem and concern worldwide. The pandemic has impacted various fields, from the social to the development of health science and technology. The virus has been mutating and thus producing several new variants, rushing research in the field of molecular biology to develop rapidly to overcome the problems that occur. Vaccine clinical studies are developing promptly with the aim of obtaining vaccines that are effective in suppressing the spread of the virus; however, the development of viral mutations raises concerns about the decreasing effectiveness of the resulting vaccine, which also results in the need for more in-depth studies. There have been 330 vaccines developed, including 136 clinical developments and 194 pre-clinical developments. The SARS-CoV-2 variant continues to evolve today, and it poses a challenge in testing the effectiveness of existing vaccines. This is a narrative review describing the emergence of the COVID-19 pandemic, development of vaccine platforms, identification of concerning mutations and virus variants in various countries of the world, and real-world monitoring of post-vaccination effectiveness and surveillance.
\end{abstract}

Keywords: COVID-19; mutated SARS-CoV-2 virus; vaccine; post vaccine surveillance

\section{Introduction}

Severe acute respiratory syndrome coronavirus-2 (SARS-CoV-2) is a highly contagious virus that emerged at the end of 2019 and has caused an upper respiratory disease pandemic, currently known as Coronavirus Disease 2019 (COVID-19) [1]. On 11 March 2020, WHO declared COVID-19 a global pandemic, and it was reported that COVID-19 had spread in 197 countries (on 25 March 2020) with a mortality rate of 18,440 and a recovery rate of 114,802 globally [2]. Efforts to defeat the COVID-19 pandemic continue to date, and vaccinations have been implemented globally. 
Until now, the SARS-CoV-2 virus continues to mutate, and there are several variants that have become a variant of concern (VOC), including B.1.1.7 (Alpha), B.1.351 (Beta), P.1 (Gamma), and B.1.617.2 (Delta). At the end of 2020, new variants emerged, namely C.37 (Lambda) and B.1.621 (Mu), which were included in the Variants of Interest (VOI) category [3]. The Alpha variant is estimated to have a $61 \%(42-82 \%)$ higher risk of death than the pre-existing variants, with greater infectiousness and disease severity [4]. P.1, another highly contagious variant, has been circulating in Brazil since the middle of 2020. This variant has been linked to an outbreak of infections in Manaus, Brazil's Amazon, which has put the healthcare system on the verge of collapsing. B.1.351 was discovered late last year in South Africa [5], while the Delta variant is known to be notoriously contagious. Within five weeks of its discovery in April-June 2021, the Delta variant became the dominant SARS-CoV-2 variant in Mesa County, Colorado, and is now the dominant variant in the United States [6]. Research to find vaccines, clinical trials, and vaccinations on a large scale to defeat the SARS-CoV-2 virus have been carried out to date, but many questions are still unanswered, including: What is the effectiveness and efficacy of the COVID-19 vaccine? Is the vaccine effective against the many SARS-CoV-2 variants? This narrative review has been prepared to answer these questions using searched and collected data on the vaccines of SARS-CoV-2 mutated virus and post-vaccination surveillance.

\section{Methods}

We used prominent search engines, namely Google Scholar, PubMed, Scopus, and BMC. The search keywords were effective and efficacy vaccine, mutated SARS-CoV-2 virus, COVID-19 vaccine variant, post-vaccination, and surveillance strategy. After the search was complete, and all duplicates were removed, then the abstracts of the remaining articles were reviewed to ensure they address the review question. Table 1 contains the inclusion criteria that were used to establish the study's relevance. The authors appraised, evaluated, and interpreted the selected articles. This narrative is reflected in the literature search (e.g., years considered, language, publication status, study design, and databases of coverage). We summarized and synthesized the findings from the selected articles and integrated them into the narrative review.

Figure 1 illustrates the PRISMA flow diagram for publication screening. The literature search described in Table 1 resulted in the discovery of 283 publications at first. The literature screening, which consisted of title, abstract, and full-text screenings, yielded 66 final publications based on the relevance of the initial papers to the established research topics for this study. Overall, only $25 \%$ of the publications initially identified in PubMed, Scopus, Google Scholar, and BMC publication databases were included in the screening processes. The approximate publications that were recorded out of publications with duplicates were indicated by the literature search results from major scholar databases such as PubMed and Scopus (Figure 1).

Table 1. List of questions used for studies inclusion and exclusion during combined title and abstract, and full-text screenings.

\begin{tabular}{|c|c|c|}
\hline Screening Stages & Questions & $\begin{array}{l}\text { Screening } \\
\text { Outcome }\end{array}$ \\
\hline Title and abstract screening & $\begin{array}{l}\text { - } \quad \text { Does the study focus on SARS-CoV-2? } \\
\text { Does the study focus on mutation in the } \\
\text { SARS-CoV-2? } \\
\text { Does the study present COVID-19 } \\
\text { vaccines? }\end{array}$ & $\begin{array}{l}\text { Studies are } \\
\text { included if they } \\
\text { satisfy all } \\
\text { questions }\end{array}$ \\
\hline
\end{tabular}


Table 1. Cont.

\begin{tabular}{|c|c|c|}
\hline Screening Stages & Questions & $\begin{array}{l}\text { Screening } \\
\text { Outcome }\end{array}$ \\
\hline Full-text screening & $\begin{array}{l}\text { Do the study present effective or } \\
\text { - } \quad \text { Does the study contain vaccines } \\
\text { containing a percent of efficacy? } \\
\text { Does the study provide the } \\
\text { effectiveness of vaccines to reduce } \\
\text { infection? } \\
\text { Does the study present the effectiveness } \\
\text { of vaccines to reduce severe/death? } \\
\text { For included studies, additional following } \\
\text { open questions are given to identify general } \\
\text { information of the studies: } \\
\text { - What is the percent of effectiveness and } \\
\text { efficacy of a vaccine? } \\
\text { What is the post-vaccination } \\
\text { surveillance strategy? } \\
\text { Publication type (e.g., J = journal article, } \\
\text { P = Proceeding Conference, T = thesis, } \\
\text { B = Book chapter, R = Report) } \\
\text { What is the type of study? (L: lab } \\
\text { measurement, R: review, O: Opinion, or } \\
\text { P: preprint) }\end{array}$ & $\begin{array}{l}\text { Studies are } \\
\text { included if they } \\
\text { satisfy at least } \\
\text { two screening } \\
\text { questions }\end{array}$ \\
\hline
\end{tabular}

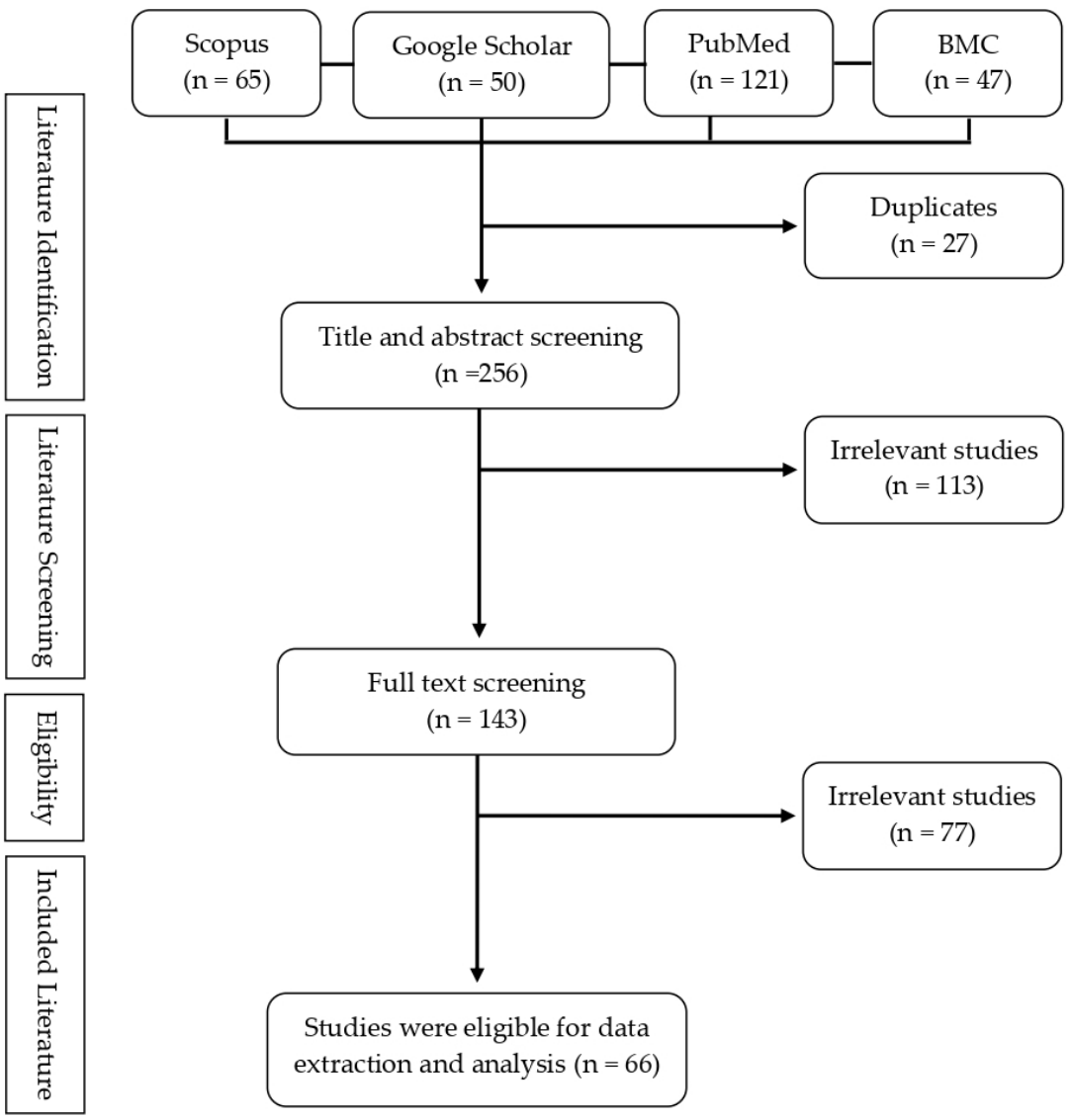

Figure 1. The PRISMA flow diagram depicts the process of selecting eligible studies. 


\section{SARS-CoV-2 and Receptors}

SARS-CoV-2 is a subfamily of Coronaviridae $(\mathrm{CoV})$, part of the Coronaviridae RNA virus family. The two types of $\mathrm{CoV}$ viruses that have caused serious illness are SARSCoV-1 that caused SARS in 2002-2003, and MERS-CoV causing MERS that occurred in the Middle East in 2012 [7]. SARS-CoV-2 was first identified by independent Chinese scientists through the bronchoalveolar lavage fluid of a patient who had severe pneumonia at the start of a COVID-19 case in Wuhan [1]. The identification results presented the presence of beta-coronavirus that showed $85 \%$ genomic similarity with the Bat-SARS-like CoV virus (bat-SL-CoVZC45, GenBank: MG772933.1); afterward, the virus was isolated and named 2019-nCoV. The electron micrograph from 2019-CoV shows the sphere shape with various diameters between 60-140 nm, with a clear spike between 9-12 $\mathrm{nm}$ in size; thus, it looks like a solar corona [8].

The SARS-CoV-2 spike protein is 1273 amino acids long, a little longer than SARS-CoV (1255 amino acids) and Bat-SARS-CoV (1245-1269 amino acids). The China National Center for Bioinformation's 2019 Novel Coronavirus Resource identified a variant of the SARSCoV-2 strain, of which 15,018 mutations were discovered worldwide [1]. Visualization of SARS-CoV-2 with transmission electron microscopy exhibited the transcriptomics of SARS-CoV-2, presented in Figure 2A-C [9].

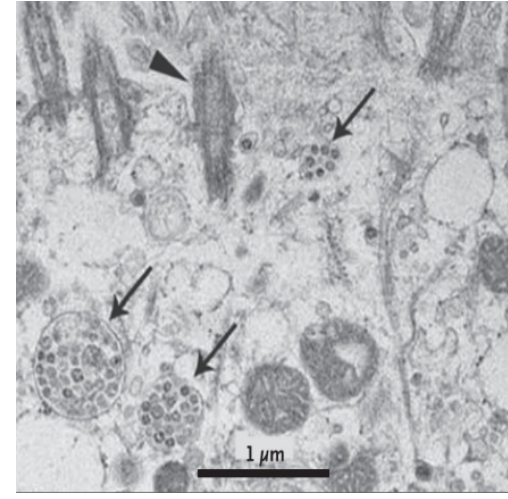

(A)

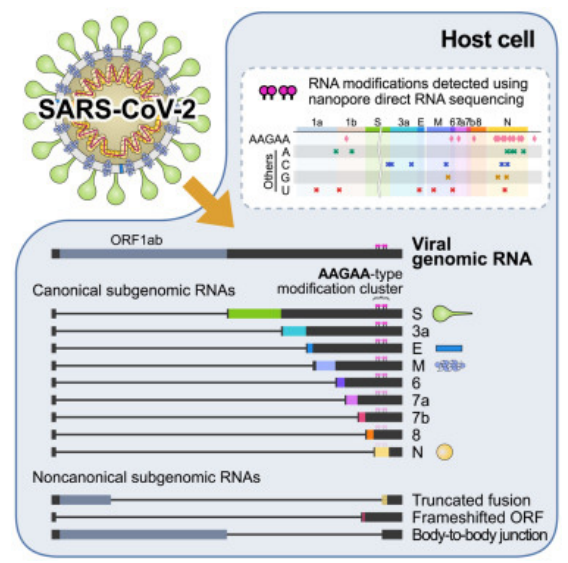

(C)

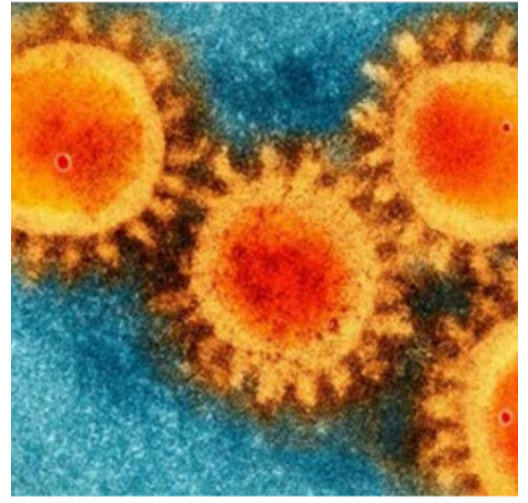

(B)

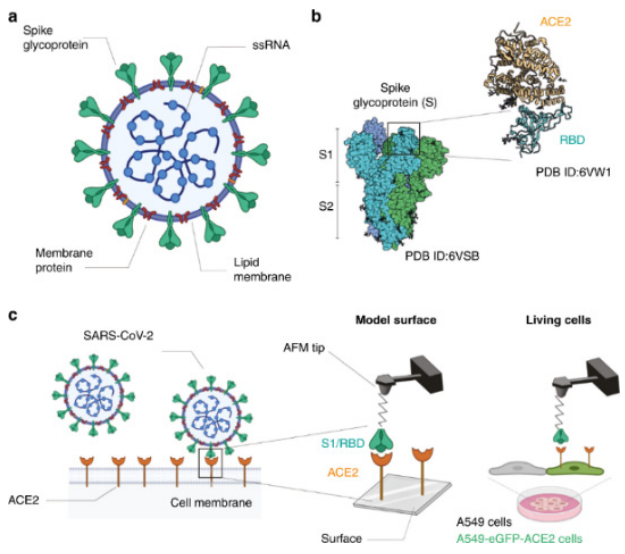

(D)

Figure 2. Visualization of SARS-CoV-2 (adapted with permission from Zhu et al., 2019; Bharadwaj et al., 2020; Kim et al., 2020 and Yang et al., 2020) [8-11] (A) Visualization of SARS-CoV-2 with Transmission Electron Microscopy (Virus particles in the human airway epithelial cell). Arrowheads represent extracellular virus particles, while arrows represent inclusion bodies generated by virus components; (B) SEM image of SARS-CoV-2 (Large protrusions emerged out from the spike of viral surface, which forms a crown-like appearance, that's why given the name 'coronavirus' (Latin word means crown)); (C) Transcriptomic (The full-length genomic RNA and nine major subgenomic RNAs); 
(D) SARS-CoV-2-ACE2 interaction (The initial attachment of SARS-CoV-2 to cells involves specific binding between the viral $S$ glycoprotein and the cellular receptor, ACE2. The interactions are monitored by AFM on model surfaces, where the ACE2 receptor is attached to a surface and the S1 subunit of the RBD onto the AFM tip, and on A549 living cells expressing or not fluorescently labeled ACE2). a. A SARS-CoV-2 particle, an enveloped ssRNA virus with the spike glycoprotein (S) on its surface that mediates binding to host cells, is depicted schematically. b. A complex between the receptor-binding domain (RBD, a subunit of the $S$ glycoprotein) and the ACE2 receptor has previously been discovered by structural research. c. A diagram depicting the use of AFM to investigate SARS-CoV-2 binding.

SARS-CoV-2 shares a 79 percent genome sequence similarity with SARS-CoV, and a 50 percent similarity with MERS-CoV. Its genome organization is similar to that of other beta-coronaviruses. The six functional open reading frames (ORFs) are arranged from $5^{\prime}$ to $3^{\prime}$ : replicase (ORF1a/ORF1b), spike $(S)$, envelope $(\mathrm{E})$, membrane $(\mathrm{M})$, and nucleocapsid $(\mathrm{N})$. The majority of the proteins encoded by SARS-CoV-2 are similar in length to the corresponding proteins in SARS-CoV. Except for the S gene, which differs, SARS-CoV-2 shares more than $90 \%$ amino acid identity with SARS-CoV [1]. The replicase $S$ gene encodes a huge polyprotein (pp1ab) that is proteolytically degraded into 16 non-structural proteins involved in transcription and viral replication. The majority of these non-structural SARSCoV-2 proteins share more than $85 \%$ of their amino acid sequence with SARS- CoV-2 [1].

SARS-CoV-2, like SARS-CoV, binds to the human angiotensin-converting enzyme 2 (ACE2) receptor. ACE-2 is a membrane receptor protein that is primarily found in adipose tissue, the kidney, the heart, and the small intestine. In humans, SARS-CoV-2 infection causes a range of symptoms from mild to severe respiratory failure. When SARS-CoV-2 binds to airway epithelial cells, it replicates, migrates, and enters alveolar epithelial cells in the lungs. This rapid replication causes a strong immune response known as a cytokine storm, which results in acute respiratory distress syndrome and respiratory failure, which are the leading causes of death in COVID-19 patients [12-14]. The upper respiratory tract provides the first line of defense in that it activates a very complex system of signaling and recruitment of immune cells in order to prevent pathogens from reaching the alveoli, the most important part of the respiratory system, as they are responsible for gas exchange. Nevertheless, SARS-CoV-2 or other coronavirus are able to reduce or delay the expression of cytokines in human lung epithelial cell lines. This is an effective system to escape immune recognition by innate receptors in the infected cell, which could therefore facilitate the progression of the virus into alveolar epithelial cells [15].

Previous research has used the force-distance (FD) curve-based atomic force microscopy to investigate the biophysical properties of the SARS-CoV-2 S-glycoprotein binding to ACE2 receptors on model surfaces and in living cells (FD-curve-based AFM). They extracted the kinetics and thermodynamics of the in vitro interactions and compared the binding properties of both the S1 subunit and the RBD. Both have been tested as potent binding inhibitor peptides targeting the viral $S$ glycoprotein, and a significant reduction in binding properties has been observed. Figure 2D depicts the SARS-CoV-2 scheme as well as the binding scheme with the ACE2 receptor [11]. Coronavirus entrance necessitates the virus's attachment to the ACE2 receptor on the host cell's surface, followed by priming by TMPRSS2. The possible SARS-CoV-2 cofactors ACE2, TMPRSS2, and FURIN are expressed largely in bronchial cells switching from secretory to ciliated identity, according to this study, which used previously unreported single-cell data from the human lung and bronchia [16].

\section{Mutation in the SARS-CoV-2}

Several variants of SARS-CoV-2 are circulating globally and have been identified, including the B.1.1.7 (Alpha) from the United Kingdom, B.1.351 (Beta) from South Africa, B.1.617.2 (Delta) from India, P.1 (Gamma) from Brazil, and B.1.1.529 (Omicron). The Alpha variant came from the UK and was first identified in December 2020 [17,18]. Although 
distinct, the Alpha and Beta variants share common characteristics, including known escape mutations discovered in vitro through antibody pressure selection [19]. The SARS-CoV2 B.1.617.2 Variant of Concern (VOC) or Delta variant, first detected in India, has now displaced the B.1.1.7 (Alpha) strain, which emerged in the UK with the second COVID-19 wave in late 2020. The B.1.617.2 variant may be transmitted at a higher rate than other variants $[17,20]$. The WHO Technical Advisory Group on SARS-CoV-2 Virus Evolution recognized the B.1.1.529 COVID-19 variant, which was first detected in Botswana and South Africa, as the Omicron variant of concern on 26 November 2021. Omicron, the SARS-CoV-2 variant responsible for a cluster of cases in South Africa and that is now spreading around the world, is the most heavily mutated variant to emerge so far and carries mutations similar to changes seen in previous variants of concern associated with enhanced transmissibility and partial resistance to vaccine-induced immunity [21].

The WHO and the NIAID directors conveyed to the public and health practitioners about a new variant called " $\mathrm{Mu}$ " in the COVID Briefing on 2 September 2021. The Muvariant is a SARS-CoV-2 variant named B.1.621, according to PANGO lineage, which was first identified in a sample of 11 January 2021 in Colombia [22]. The status of Mu-variant in the world is designated as a VOI by WHO on 30 August 2021. According to WHO data, the distribution of Mu-variant in the world as of 1 September 2021 has been found in at least 39 countries [3]. The Mu-variant carried at least 21 point mutations in the genetic material of SARS-CoV-2, of which nine were in the viral spike protein. This variant carries several key mutations previously known in other variants. The key mutation carried by the Mu-variant is N501Y (as in the Alpha-variant); E484K (as in the Beta-variant); P681H (as in the Delta-variant) [23].

WHO decided to monitor this variant because the combination of mutations carried by the Mu-variant has the potential to decrease antibody neutralization, as shown in early studies of convalescent plasma and vaccine sera (however, the scientists from the Virus Evolution Working Group agree that further research is needed). Its global prevalence continues to decline (currently $<0.1 \%$ ); however, this variant is still under scrutiny due to its consistent development in Ecuador and Colombia $[3,24]$. The WHO Virus Evolution Working Group (now called the Technical Advisory Group on Virus Evolution) released recent enhancing readiness for Omicron (B.1.1.529): technical brief and priority actions for WHO members on 10 December 2021. It has been mentioned that the current understanding of the Omicron variant based on recent data is likely to evolve as more data becomes available.

\section{Types of COVID-19 Vaccines}

Over the last few decades, advances in molecular biology and vaccinology have resulted in the development of a diverse range of novel vaccine platform technologies. These platform technologies include live pathogen inactivation and targeted attenuation to the delivery of synthetic peptide antigens and recombinant protein antigens, as well as viruslike particles (VLPs), non-replicating and replicating viral vectors, polysaccharide-protein conjugates, and nucleic acid-based (DNA and RNA) vaccines. Many of the currently marketed vaccines against infectious diseases are based on these platform technologies [25,26]. The COVID-19 Vaccine Development Platform consists of the following components: inactivated whole SARS-CoV-2, DNA-based vaccine (plasmid DNA expressing S protein), m-RNA-based vaccine (receptor binding domain of spike protein), subunit vaccine (recombinant spike protein), and vector-based vaccine (replicating or non-replicating viral vector used for the delivery of spike protein). Figure 3 depicts the COVID-19 Vaccine Development Platform [27].

Based on data from WHO as of 7 December 2021, there are currently 330 COVID-19 vaccines under development, with 136 vaccine candidates having entered the clinical-phase trial and 194 others still in the pre-clinical phase. Among the vaccine candidate platforms currently being tested are protein subunit 47 (35\%), viral vector non-replicating 20 (15\%) and replicating 2 (1\%), DNA based vaccines $15(11 \%)$, mRNA based vaccines 22 (16\%), and 
inactivated virus $13(13 \%)$. According to the 136 types of vaccines that have been clinically tested, 10 vaccines have reached stage 4 clinical trials [28].

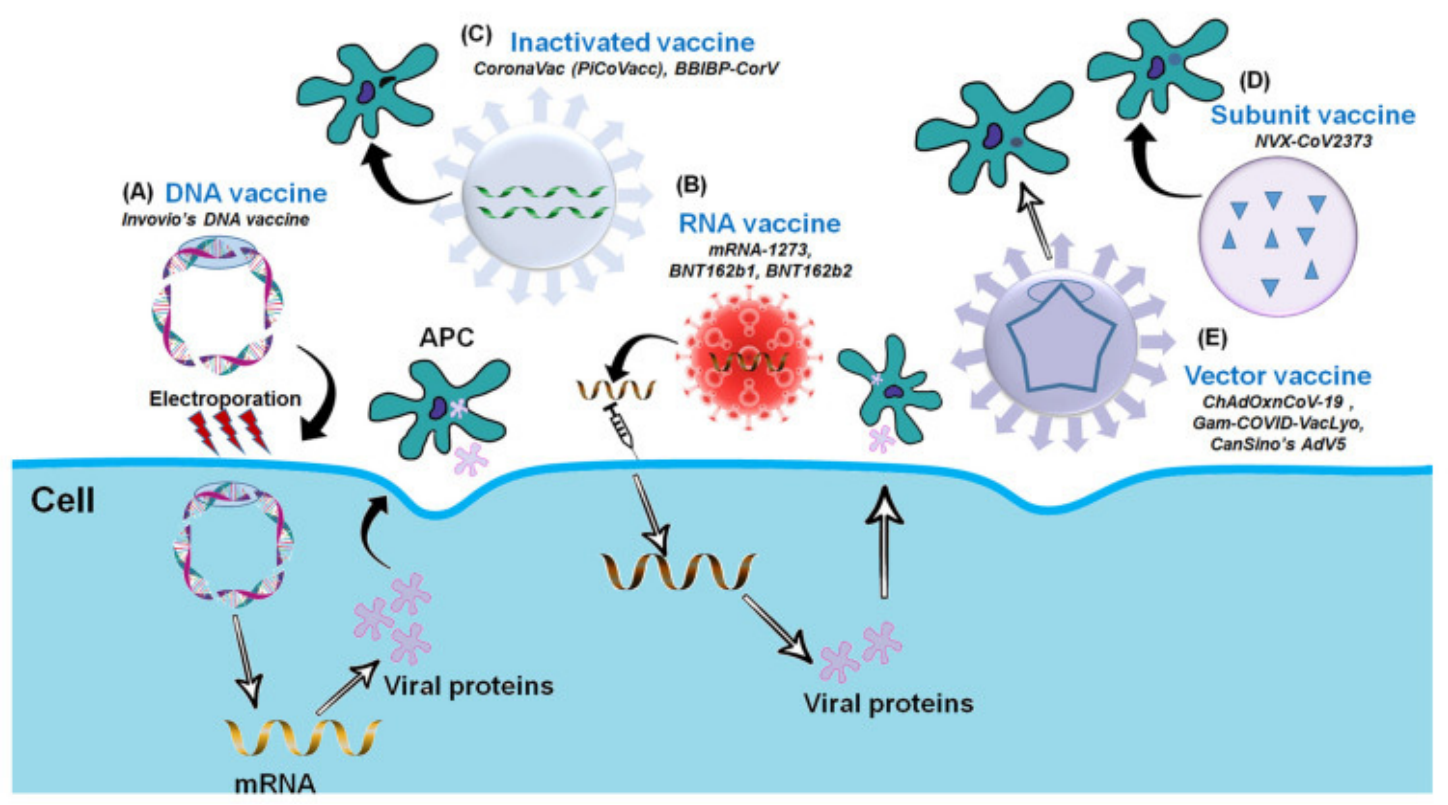

Figure 3. The Platform for COVID-19 Vaccine (adapted with permission from Ashraf et al., 2021) [27]. Platforms for the COVID-19 Vaccine Development. (A) DNA vaccine: Plasmid DNA expressing S protein. (B) RNA vaccine: mRNA-based (RBD of S-protein). (C) Inactivated vaccine: Inactivated whole SARS-CoV-2. (D) Subunit vaccine: Recombinant S-protein and (E) Vector-based vaccine: Replicating or Non-replicating viral vector used for the delivery and expression of $S$ protein.

\subsection{Inactivated Virus-Based Vaccines}

Pre-clinical studies have been conducted on a number of COVID-19 vaccine candidates based on well-established technology. This method is based on an existing technology platform for pathogen inactivation in blood products, in which ultraviolet light and riboflavin are used to inactivate the virus through targeted damage to nucleic acids, while proteins and viral antigens are preserved. This technique has been shown to be effective in inactivating MERS-CoV. The development of conventional inactivated vaccines necessitates the cultivation of high titers of infectious virus, which, in the case of SARS-CoV-2, must take place in biosafety level 3 facilities, posing a major safety concern. Furthermore, incomplete virus inactivation poses a potential risk to vaccine production workers, as well as the possibility of disease outbreaks in vaccinated populations and the induction of harmful immune or inflammatory responses [26,29].

CoronaVac is a vaccine with an inactivated virus-based platform. This vaccine has varying efficacy, with the latest efficacy results from phase 3 clinical trials in Indonesia showing this vaccine is quite effective with $65.3 \%$ efficacy after the second dose of 1620 participants aged $18-59$ years [30].

\subsection{DNA-Based Vaccines}

The introduction of the DNA vaccine, which encodes for the antigen and an adjuvant that induces the adaptive immune response, has been the most revolutionary approach to vaccination. The transfected cells express the transgene, supplying a steady supply of transgene-specific proteins that are very similar to the live virus [31]. In the form of DNA, this vaccination comprises a subset of the virus's genes. The DNA is employed as a template for in situ expressions of possibly innocuous viral proteins, which trigger a protective immune response after injection. The safety and scalability for large production are two of the most significant advantages of this type of vaccine. 
The DNA has to enter the nucleus in order to be transcribed. The worry arises in terms of the potential long-term risk of tumorigenicity, especially when injected into young people. These concerns are supported by a document issued by the FDA under the title "Long-Term Follow-up after Administration of Human Gene Therapy Products, Guidance for Industry" [32]. In contrast, a 1997 study found that parenteral administration of hybridoma DNA does not result in the development of local tumors. Furthermore, there was no evidence of the hybridoma DNA's systemic carcinogenic potential [33]. Behind the conflicting DNA-based vaccine platforms, there are several vaccines being developed, including INO-480+electroporation, nCov vaccine, AG0301-COVID19, and GX-19N [28].

\section{3. $m R N A$-Based Vaccines}

RNA vaccines contain virus genes in the form of mRNA, which is then translated into viral proteins after cytosolic delivery. The mRNA is a new, non-infectious, and non-integrating platform with almost no risk of insertional mutagenesis. Currently, nonreplicating RNA and virus-derived self-replicating RNAs are being studied. The immunogenicity of the mRNA can be reduced, and changes can be made to improve the stability of these vaccines $[26,31]$.

The mRNA-1273 vaccine, developed by Moderna Therapeutics (Cambridge, MA, USA) and the National Institute of Allergy and Infectious Disease (NIAID), was the first candidate vaccine to enter Phase I clinical testing, just 42 days after the full SARS-CoV-2 genome was sequenced (ClinicalTrials.gov identifier NCT04283461) [34,35].

Recent studies of the BNT162b2 vaccine have shown that after 6 months of use, the vaccine is safe and has acceptable adverse events. The efficacy of this vaccine reaches $91.3 \%$ and has a high efficacy advantage in dealing with beta variants [36]. In phase 4 clinical trials, the vaccine was tested as a booster or third dose in participants aged over 16 years and patients with multiple sclerosis [37-39].

\subsection{Protein Subunit-Based Vaccine}

Vaccines based on synthetic peptides or recombinant antigenic proteins are known as subunit vaccines. Subunit vaccines have low immunogenicity and require adjuvant support to enhance the vaccine-induced immune response. Subunit vaccines contain only specific viral antigenic fragments and no additional pathogenic virus components. As a result, this method eliminates concerns about incomplete viral inactivation, virulence recovery, and pre-existing anti-vector immunity. As a result, subunit vaccines are widely regarded as extremely safe. Furthermore, subunit vaccines can specifically target wellcharacterized neutralizing antigenic epitopes and improve immunogenicity and/or efficacy when combined with adjuvants. Adjuvants can extend the antigenic material's biological half-life or improve the immunomodulatory cytokine response [26].

Vaccines developed with this model include NVX-CoV2373 (Novavax, Inc.). In an animal model, it demonstrated high immunogenicity by measuring anti-spike antibodies, which prevent the spike protein from attaching to the receptor, as well as wild-type virusneutralizing antibodies [31]. Adult participants were given a two-dose regimen of the NVXCoV2373 vaccine, which provided 89.7 percent protection against SARS-CoV-2 infection and demonstrated high efficacy against the B.1.1.7 variant [40].

\subsection{Viral Vector-Based Vaccine}

A vaccine based on viral vectors is a promising anti-pathogen treatment. These vaccines are highly specific in terms of delivering genes to target cells, efficient in terms of gene transduction, and, once again, inducing an immune response. They provide a long-term and high level of antigenic protein expression and thus have a high potential for prophylactic use, as these vaccines activate and prime cytotoxic T cells (CTL), resulting in the elimination of virus-infected cells [31,41]. Viral vectors are used to deliver vaccine antigens to target cells or tissues, and both replicating and non-replicating viral vectors are 
available. Adenoviruses and poxviruses are examples of viral vectors of replicating and non-replicating forms.

One of the viral vector vaccine platforms that have been used today is $\mathrm{ChAcOx} 1 \mathrm{nCoV}$ 19 (AstraZeneca and Oxford). Based on clinical trial data from 17,177 people consisting of 8948 in the UK, 6753 in Brazil, and 1476 in South Africa, showed high safety and efficacy in participants aged $18-55$ years [42].

\section{Efficacy and Effectiveness of COVID-19 Vaccines}

To determine the effectiveness and efficacy of the vaccine against the SARS-CoV2 mutant, Weissman and colleagues conducted experiments using the serum of mice, non-human primates, and humans. Experiments were carried out using a pseudovirus containing spike D614 or G614. The results showed that mice, non-human primates, and humans vaccinated using the mRNA-LNP platform produced an antibody response that not only recognized the G614 mutation but also had stronger neutralization titers against this viral variant [43-45].

The study used a pseudovirus that expresses a wild-type spike protein or a mutated spike protein containing eight amino acid changes, detected in the variant B. 1.1.7, to assess the immune response of individuals after vaccination with the BNT162b22 mRNAbased vaccine by measuring the neutralizing antibody response after the first and second immunization. Individuals who received the vaccine had variable neutralizing titers against the wild-type pseudovirus in their blood, which were slightly lower against variation B.1.1.7. Some individuals who had recovered from COVID-19 showed this drop in their serum as well [46].

Another Brazilian variation, P.1, was found to be resistant to not only some neutralizing monoclonal antibodies but also to neutralization by convalescent plasma and vaccination serum in a prior investigation. With the pseudovirus and native P.1 virus, the level of resistance was greater for monoclonal antibodies than for vaccine serum. The P.1 trimer only assumes a conformation in which one of the receptor-binding domains is in the "up" position, which is known to enhance binding to the ACE2 entry receptor, according to the cryoelectron microscopy structure of the soluble prefusion stabilized spike. Local rather than global conformational alterations appear to be the source of the P.1 mutation's functional impact. Current antibody therapy is threatened by the P.1 mutation, but vaccination efficacy is limited $[47,48]$.

Furthermore, a study was carried out to see if monoclonal antibodies, convalescent serum, and vaccinations might neutralize B.1.617.1 and B.1.617.2, as well as a structural analysis of the Fab/receptor-binding domain (RBD) complex and a map of the antigenic space of variant flows. When compared to the Wuhan-associated ancestor strain, neutralization of both viruses was reduced, but there was no evidence of broad antibody release, as reported in B.1.351. However, serum B.1.351 and P.1 showed a greater drop in B.1.617.2 neutralization, suggesting that people who have been infected with this variety before may be more susceptible to reinfection with B.1.617.2 [49]. Although it has 12 mutations in its spike protein relative to the wild type SARS-CoV-2, which was first detected in Wuhan, China, in December 2019, B.1.617.2 lacks mutations at amino acid positions 501 or 484 in its ACE2 receptor-binding domain, which is commonly associated with VOCs or escapes from neutralizing antibodies (NAbs) [50]. Previous studies have shown an effective vaccine against the Delta-variant in the world. A program called UK-REACT-1, led by the Imperial College London team, tested more than 100,000 volunteers in the UK every few weeks. Ct analysis from the PCR was carried out for samples from May-July 2021, when the Deltavariant became dominant in the UK. Volunteers were tested by PCR as well as sequential genome sequencing to confirm confirmed SARS-CoV-2 infections and the Delta-variant in infected individuals. Paul Elliot, one of the members of the research team, noted the strength of the study because it took a random sample of the population and included people who tested positive but were asymptomatic. The results of a large-scale study exhibit among individuals who tested positive for COVID-19 showed the following [51,52]: 
(1) Vaccinated individuals are estimated to have lower viral loads compared to the unvaccinated;

(2) Vaccinated individuals exhibit milder symptoms compared to unvaccinated ones;

(3) The UK implemented a fairly rapid vaccination program to protect the population (currently, it has reached $70 \%-80 \%$ of the total population, with vaccines used including Pfizer, Moderna, AstraZeneca, and Johnson \& Johnson).

Vaccine platforms that have been developed and passed phase 3 clinical trials and have been used to overcome the COVID-19 pandemic in various countries, including Pfizer-BioNTech, Moderna, AstraZeneca-Oxford, Janssen, Sputnik V, CanSino, Sinovac, and Sinopharm. Table 2 contains data on its efficacy and effectiveness in combating the COVID-19 pandemic and its variants, whereas Table 3 displays data on its effectiveness against severe disease.

Based on the data collected in the Tables 2 and 3, it is known that various variants of SARS-CoV-2 are able to reduce the effectiveness of several vaccines that have received approval. However, vaccination can increase the severity of the case-fatality reduction. Not all vaccines have published data regarding their effectiveness and efficacy against various VoCs. The efficacy and effectiveness of vaccination in a pandemic is not only influenced by the infecting variant, but internal factors such as age, comorbidities, and even race, have the possibility of influencing these numbers. This is an opportunity to publicize the real conditions experienced in health care facilities along with the mass vaccination process that is still being carried out in various parts of the world. 
Table 2. Efficacy and effectiveness of COVID-19 vaccines that have received emergency use authorization against various SARS-CoV-2 variants [28,53-56].

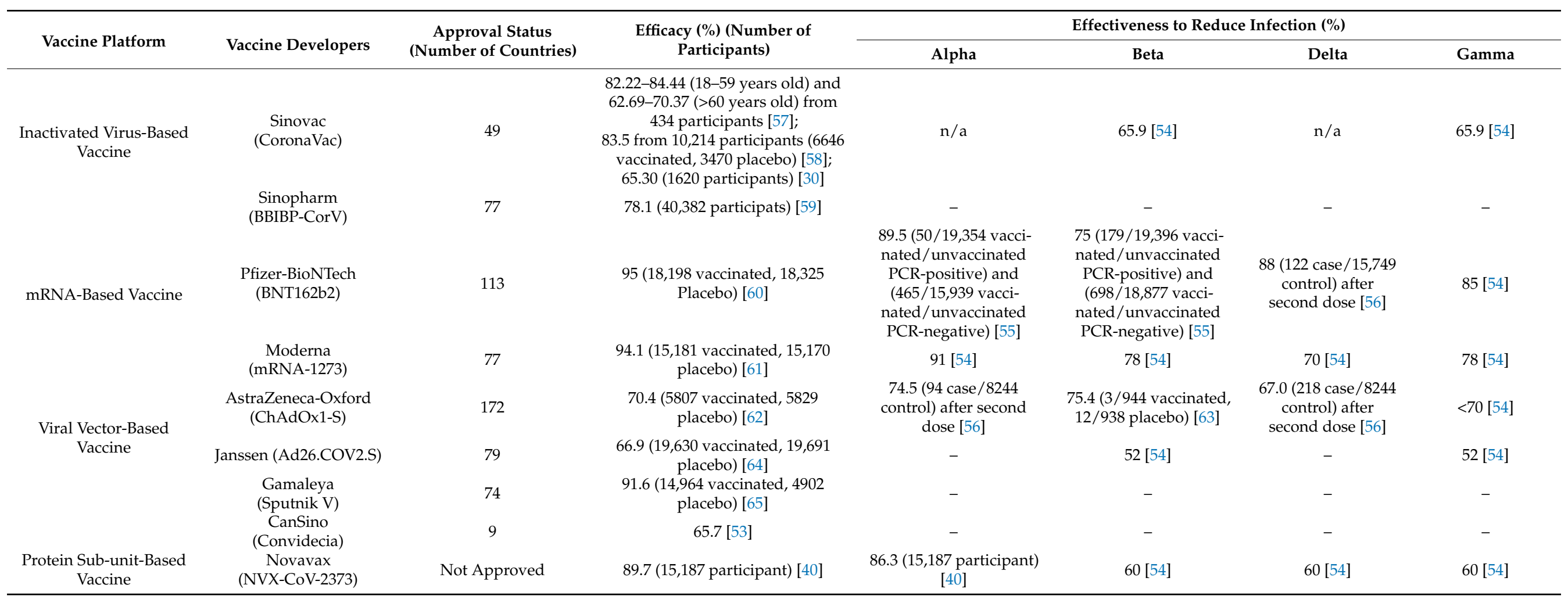


Table 3. Effectiveness of COVID-19 vaccines against severe disease [54,55].

\begin{tabular}{|c|c|c|c|c|c|c|c|c|}
\hline \multirow{2}{*}{ Vaccine Developers } & \multicolumn{8}{|c|}{ Effectiveness to Reduce Severe Disease/Death (\%) } \\
\hline & Alpha & Participants & Beta & Participants & Delta & Participants & Gamma & Participants \\
\hline $\begin{array}{c}\text { Sinovac } \\
\text { (CoronaVac) }\end{array}$ & $\mathrm{n} / \mathrm{a}$ & $\mathrm{n} / \mathrm{a}$ & 87.5 & $\mathrm{n} / \mathrm{a}$ & $\mathrm{n} / \mathrm{a}$ & $\mathrm{n} / \mathrm{a}$ & 87.5 & $\mathrm{n} / \mathrm{a}$ \\
\hline $\begin{array}{l}\text { Pfizer-BioNTech } \\
\text { (BNT162b2) }\end{array}$ & $\begin{array}{c}54.1 \text { (after one } \\
\text { dose) [55] } \\
\text { 100.0 (after second } \\
\text { dose) [55] }\end{array}$ & $\begin{array}{c}\text { PCR-positive: } \\
30 \text { vaccinated/468 } \\
\text { unvaccinated } \\
\text { PCR-negative: } 61 / 437 \\
\text { PCR-positive: } 0 / 401 \\
\text { PCR negative: } 20 / 381\end{array}$ & $\begin{array}{c}100.0 \text { (after second } \\
\text { dose) [55] }\end{array}$ & $\begin{array}{l}\text { PCR-positive: 0/300 } \\
\text { PCR-negative: } 14 / 246\end{array}$ & 95 & $\mathrm{n} / \mathrm{a}$ & 98 & $\mathrm{n} / \mathrm{a}$ \\
\hline $\begin{array}{c}\text { Moderna } \\
\text { (mRNA-1273) }\end{array}$ & 94 & $\mathrm{n} / \mathrm{a}$ & 94 & $\mathrm{n} / \mathrm{a}$ & 96 & $\mathrm{n} / \mathrm{a}$ & 94 & $\mathrm{n} / \mathrm{a}$ \\
\hline $\begin{array}{l}\text { AstraZeneca-Oxford } \\
\text { (ChAdOx1-S) }\end{array}$ & 95 & $\mathrm{n} / \mathrm{a}$ & $\mathrm{n} / \mathrm{a}$ & $\mathrm{n} / \mathrm{a}$ & 95 & $\mathrm{n} / \mathrm{a}$ & $\mathrm{n} / \mathrm{a}$ & $\mathrm{n} / \mathrm{a}$ \\
\hline $\begin{array}{c}\text { Janssen } \\
\text { (Ad26.COV2.S) }\end{array}$ & $\mathrm{n} / \mathrm{a}$ & $\mathrm{n} / \mathrm{a}$ & $\begin{array}{c}65-66 \\
\text { (hospitalization) } \\
91-95 \text { (mortality) }\end{array}$ & $\mathrm{n} / \mathrm{a}$ & 71 & $\mathrm{n} / \mathrm{a}$ & $\begin{array}{c}65-66 \\
\text { (hospitalization) } \\
91-95 \text { (mortality) }\end{array}$ & $\mathrm{n} / \mathrm{a}$ \\
\hline
\end{tabular}




\section{Post-Vaccination Surveillance Strategy}

Post-vaccination monitoring needs to be carried out considering the vaccines used have not been completed in clinical trials and the limited number of participants in clinical trials. In practice, several problems were reported, such as death from blood clots after vaccination and other serious effects. Post-vaccination monitoring can be done using two pharmacology approaches, namely pharmacovigilance and pharmacoepidemiology. Pharmacovigilance, also known as drug safety surveillance, is primarily concerned with the timely identification of novel adverse drug reactions (ADRs) that are distinct in clinical nature, severity, and/or frequency. Pharmacoepidemiology is the population-based study of drug use and the risks associated with it. The importance of using pharmacovigilance should be emphasized by highlighting that the life of a drug truly begins after marketing [66,67].

The FDA Adverse Event Reporting System (FAERS) was created in the United States to gather ADRs from healthcare providers, patients, and pharmaceutical corporations. FAERS intends to support pharmaceutical and biological product post-marketing surveillance initiatives [68,69]. In Europe, the European Medicines Agency (EMA) established the Pharmacovigilance Risk Assessment Committee, which is in charge of all aspects of medicine safety assessment and monitoring. In the EudraVigilance database, adverse events are noted, recorded, and analyzed, and it is regarded as one of the world's largest databases, with over 16.7 million individual case safety reports (ICSRs) [70].

Besides, in Indonesia, the Food and Drug Supervisory Agency (Badan Pengawas Obat dan Makanan/BPOM) monitors the safety, efficacy, and quality of COVID-19 vaccines. In order to guarantee requirements compliance, the BPOM continues to supervise the implementation of clinical trials, including evaluation process accelerate for grant of the Clinical Trial Protocol Approval (Persetujuan Protokol Uji Klinik/PPUK), and thereafter inspections ensuring that clinical trials are conducted in accordance with the approved clinical trial protocols, and also regulations implementation of Good Clinical Practice (GCP). Monitoring of the clinical trial subject safety was established by the Health Research Ethics Committee of Padjadjaran University. The BPOM has implemented comprehensive inspections of vaccine production facilities to warrant that manufacturers apply Good Manufacturing Practices (GMP) standards throughout the vaccine manufacturing process, consistently commence the manufacture of vaccine raw materials (upstream), and thereafter vaccine formulation (downstream), until the process of vial filling for acquiring the endproduct. Furthermore, the entire data (safety, efficacy, and quality aspects) is compulsorily submitted by the pharmaceutical industry to the BPOM for an evaluation process that refers to national and international evaluation guideline standards. The evaluation process is conducted via conferences with the National Committee for Drug Evaluation, experts, and clinicians from the Indonesian Doctors Association (Ikatan Dokter Indoensia/IDI). Specifically for vaccines, conferences have been organized with the Indonesian Technical Advisory Group on Immunization (ITAGI) [71].

At the international level, the WHO Uppsala Monitoring Center (UMC) maintains a large database of ADR reports known as "VigiBase" [72]. VigiBase is the WHO's one-ofa-kind global database of individual case safety reports (ICSRs). It is the world's largest database of its kind, with over 25 million reports of suspected adverse effects of medicines submitted by member countries of the WHO Program for International Drug Monitoring since 1968. It is constantly updated with new reports [73]. In addition, Ontario will analyze the effectiveness of COVID-19 vaccines against a variety of outcomes and subgroups of interest using linked data at ICES (e.g., age group and comorbidities). The goal of this study is to determine how effective immunizations are against laboratory-confirmed COVID19 infection (symptomatic and asymptomatic) as well as clinical severity assessments, including hospitalization and mortality. Vaccine efficacy (VE) assessments will also look at how successful the vaccine is after one and two doses, as well as VE against SARSCoV-2 subtypes (i.e., variants of concern) [74]. It is critical to evaluate the performance of COVID-19 vaccines as part of post-implementation surveillance in the context of "real world" program implementation, which includes immunization of some groups excluded 
from trials (e.g., LTC residents, immunosuppressed, and pregnant individuals) and the use of an extended second dose interval (with some exceptions) [74].

Several vaccine effectiveness studies in the United Kingdom (UK) have found that two doses of COVID-19 with the Delta variant vaccination are between 65 and 95 percent effective at avoiding symptomatic disease, with higher levels of protection against severe disease, including hospitalization and death. Protection against infection and symptomatic disease appears to wane over time; however, protection against severe disease remains high in most groups at least 5 months after the second dose. Vaccine coverage, proof of vaccine effectiveness, and the most recent COVID-19 disease surveillance indicators are used to analyze the vaccination program's effects on the population. Vaccine coverage indicates the percentage of people who have received one or two doses of COVID-19 vaccine. By 10 October 2021, 65.5\% of people in England had received one dose of the vaccine, and $60.4 \%$ had received two doses of the vaccine. According to the program's launch, the oldest age groups have the most coverage. COVID-19 cases, hospitalizations, and deaths are broken down by vaccination status. According to blood donor antibody testing, $98.0 \%$ of adults now have antibodies to COVID-19 from infection or vaccination, compared to $18.7 \%$ who have antibodies from infection alone. The effectiveness of vaccines is determined by comparing disease rates in vaccinated and unvaccinated people [75]. The summary of the latest real-world information on vaccine effectiveness from research in UK populations (concentrating on information about the Delta variety, which is currently the most common in the UK) is shown in Table 4 as well [75].

Table 4. Evidence on the effectiveness of the vaccine against various outcomes Delta variant.

\begin{tabular}{|c|c|c|c|}
\hline \multirow[b]{2}{*}{ Outcome } & \multicolumn{3}{|c|}{ Vaccine Effectiveness * } \\
\hline & $\begin{array}{l}\text { Pfizer-BioNTech } \\
\text { Cominarty }\end{array}$ & $\begin{array}{c}\text { AstraZeneca } \\
\text { Vaxzevria }\end{array}$ & $\begin{array}{l}\text { Moderna } \\
\text { Spikevax }\end{array}$ \\
\hline Infection & $75-85 \%$ & $60-70 \%$ & - \\
\hline Symptomatic disease & $80-90 \%$ & $65-75 \%$ & $90-99 \%$ \\
\hline Hospitalization & $95-99 \%$ & $90-99 \%$ & $95-99 \%$ \\
\hline Mortality & $90-99 \%$ & $90-95 \%$ & - \\
\hline
\end{tabular}

Phase 3 vaccine studies are conducted in well-defined populations that may exclude some categories, such as immunocompromised people, pregnant women, and children. These tests are carried out in optimal settings, with excellent cold chain storage and maintenance, and the recommended interval between dosages is strictly followed. It is crucial to assess effectiveness as it is used in the real world, as this may differ from clinical trial efficacy. Clinical studies are usually powered for a primary goal of virologically verified symptomatic disease within a short follow-up time so that efficacious vaccinations can be introduced as quickly as possible. Understanding the effectiveness against different endpoints (such as disease severity and onward transmission), effectiveness in different subgroups of the population, and duration of effectiveness are all important factors in deciding which vaccines to use as the program evolves, whom to offer them to, and whether booster doses are necessary. Using a screening and test-negative case control method, the expanded surveillance will be utilized to monitor age-specific vaccine effectiveness in targeted populations, as well as identify risk factors for and outcomes of vaccine failure [76].

Author Contributions: Conceptualization, I.H., D.N.I. and M.B.; methodology, I.H., D.N.I., M.B. and O.M.; validation, formal analysis, investigation, D.N.I., M.B., I.H. and O.M.; resources, M.B.; data curation, I.H., D.N.I. and M.B.; writing—original draft preparation, I.H., D.N.I. and M.B.; writingreview and editing, I.H., D.N.I., M.B., O.M., A.R.H.U., G.A.S., A.S., I.E.S. and D.D.; visualization, D.N.I.; supervision, M.B., A.R.H.U. and A.S.; project administration, M.B.; funding acquisition, M.B. All authors have read and agreed to the published version of the manuscript. 
Funding: This work was funded by the Ministry of Education, Culture, Research and Technology Republic of Indonesia under the World Class University Program of Universitas Sumatera Utara Year 2021 (No. 2/UN5.2.3.1/PPM/KP-WCU-I/2021).

Institutional Review Board Statement: Not applicable.

Informed Consent Statement: Not applicable.

Data Availability Statement: No additional data is available for this paper.

Conflicts of Interest: The authors declare no conflict of interest.

\section{References}

1. Hu, B.; Guo, H.; Zhou, P.; Shi, Z.-L. Characteristics of SARS-CoV-2 and COVID-19. Nat. Rev. Microbiol. 2021, 19, 141-154. [CrossRef]

2. Baloch, S.; Baloch, M.A.; Zheng, T.; Pei, X. The Coronavirus Disease 2019 (COVID-19) Pandemic. Tohoku J. Exp. Med. 2020, 250, 271-278. [CrossRef]

3. WHO. Tracking SARS-CoV-2 Variants. Available online: https://www.who.int/en/activities/tracking-SARS-CoV-2-variants (accessed on 5 September 2021).

4. $\quad$ Davies, N.G.; Jarvis, C.I.; CMMID COVID-19 Working Group; Edmunds, W.J.; Jewell, N.P.; Diaz-Ordaz, K.; Keogh, R.H. Increased mortality in community-tested cases of SARS-CoV-2 lineage B.1.1.7. Nature 2021, 593, 270-274. [CrossRef]

5. Burki, T. Understanding variants of SARS-CoV-2. Lancet 2021, 397, 462. [CrossRef]

6. Herlihy, R.; Bamberg, W.; Burakoff, A.; Alden, N.; Severson, R.; Bush, E.; Kawasaki, B.; Berger, B.; Austin, E.; Shea, M.; et al. Rapid Increase in Circulation of the SARS-CoV-2 B.1.617.2 (Delta) Variant-Mesa County, Colorado, April-June 2021. Morb. Mortal. Wkly. Rep. 2021, 70, 1084-1087. [CrossRef]

7. Platto, S.; Wang, Y.; Zhou, J.; Carafoli, E. History of the COVID-19 pandemic: Origin, explosion, worldwide spreading. Biochem. Biophys. Res. Commun. 2020, 538, 14-23. [CrossRef]

8. Zhu, N.; Zhang, D.; Wang, W.; Li, X.; Yang, B.; Song, J.; Zhao, X.; Huang, B.; Shi, W.; Lu, R.; et al. A Novel Coronavirus from Patients with Pneumonia in China, 2019. N. Engl. J. Med. 2020, 382, 727-733. [CrossRef]

9. Kim, D.; Lee, J.-Y.; Yang, J.-S.; Kim, J.W.; Kim, V.N.; Chang, H. The Architecture of SARS-CoV-2 Transcriptome. Cell 2020, 181, 914-921.e10. [CrossRef] [PubMed]

10. Bharadwaj, A.; Wahi, N.; Saxena, A.; Chaudhary, D. Proteome Organization of COVID-19: Illustrating Targets for Vaccine Development. J. Pure Appl. Microbiol. 2020, 14, 831-840. [CrossRef]

11. Yang, J.; Petitjean, S.J.L.; Koehler, M.; Zhang, Q.; Dumitru, A.C.; Chen, W.; Derclaye, S.; Vincent, S.P.; Soumillion, P.; Alsteens, D. Molecular interaction and inhibition of SARS-CoV-2 binding to the ACE2 receptor. Nat. Commun. 2020, 11, 4541. [CrossRef]

12. Hu, B.; Huang, S.; Yin, L. The cytokine storm and COVID-19. J. Med. Virol. 2021, 93, 250-256. [CrossRef]

13. Ye, Q.; Wang, B.; Mao, J. The pathogenesis and treatment of the 'Cytokine Storm' in COVID-19. J. Infect. 2020, 80, 607-613. [CrossRef]

14. Das, G.; Ghosh, S.; Garg, S.; Ghosh, S.; Jana, A.; Samat, R.; Mukherjee, N.; Roy, R.; Ghosh, S. An overview of key potential therapeutic strategies for combat in the COVID-19 battle. RSC Adv. 2020, 10, 28243-28266. [CrossRef]

15. Carcaterra, M.; Caruso, C. Alveolar Epithelial Cell Type II as Main Target of SARS-CoV-2 Virus and COVID-19 Development via NF-Kb Pathway Deregulation: A Physio-Pathological Theory. Med. Hyphotheses 2021, 146, 110412. [CrossRef]

16. Lukkasen, S.; Chua, R.L.; Trefzer, T.; Kahn, N.C.; Schneider, M.A.; Muley, T.; Winter, H.; Mesiter, M.; Veith, C.; Boots, A.W.; et al. SARS-CoV-2 Receptor ACE2 and TMPRSS2 Are Primarily Expressed in Bronchial Transient. EMBO J. 2020, 39 , e105114. [CrossRef]

17. Anonymous. SARS-CoV-2 Variant Classifications and Definitions. Available online: https://www.cdc.gov/coronavirus/2019 -ncov/variants/variant-info.html (accessed on 28 October 2021).

18. Firestone, M.J.; Lorentz, A.J.; Wang, X.; Como-Sabetti, K.; Vetter, S.; Smith, K.; Holzbauer, S.; Meyer, S.; Ehresmann, K.; Danila, R.; et al. First Identified Cases of SARS-CoV-2 Variant B.1.1.7 in Minnesota-December 2020-January 2021. MMWR Morb. Mortal. Wkly. Rep. 2021, 70, 278-279. [CrossRef]

19. Planas, D.; Bruel, T.; Grzelak, L.; Guivel-Benhassine, F.; Staropoli, I.; Porrot, F.; Planchais, C.; Buchrieser, J.; Rajah, M.M.; Bishop, E.; et al. Sensitivity of infectious SARS-CoV-2 B.1.1.7 and B.1.351 variants to neutralizing antibodies. Nat. Med. 2021, 27, 917-924. [CrossRef] [PubMed]

20. Dougherty, K.; Mannell, M.; Naqvi, O.; Matson, D.; Stone, J. SARS-CoV-2 B.1.617.2 (Delta) Variant COVID-19 Outbreak Associated with a Gymnastics Facility-Oklahoma, April-May 2021. MMWR Morb. Mortal. Wkly. Rep. 2021, 70, 1004-1007. [CrossRef]

21. Torjesen, I. Covid-19: Omicron may be more transmissible than other variants and partly resistant to existing vaccines, scientists fear. BMJ 2021, 375, n2943. [CrossRef] [PubMed]

22. Anonymous. Lineage B.1.621. Available online: https://cov-lineages.org/lineage.html?lineage=B.1.621 (accessed on 5 September 2021).

23. Anonymous. B.1.621 Lineage Report. Available online: https://outbreak.info/situation-reports?pango=B.1.621 (accessed on 5 September 2021). 
24. Messali, S.; Bertelli, A.; Campisi, G.; Zani, A.; Ciccozzi, M.; Caruso, A.; Caccuri, F. A cluster of the new SARS-CoV-2 B.1.621 lineage in Italy and sensitivity of the viral isolate to the BNT162b2 vaccine. J. Med. Virol. 2021, 93, 6468-6470. [CrossRef]

25. Lurie, N.; Saville, M.; Hatchett, R.; Halton, J. Developing Covid-19 Vaccines at Pandemic Speed. N. Engl. J. Med. 2020, 382, 1969-1973. [CrossRef]

26. Frederiksen, L.S.F.; Zhang, Y.; Foged, C.; Thakur, A. The Long Road Toward COVID-19 Herd Immunity: Vaccine Platform Technologies and Mass Immunization Strategies. Front. Immunol. 2020, 11, 1817. [CrossRef] [PubMed]

27. Ashraf, M.; Kim, Y.; Kumar, S.; Seo, D.; Ashraf, M.; Bae, Y.-S. COVID-19 Vaccines (Revisited) and Oral-Mucosal Vector System as a Potential Vaccine Platform. Vaccines 2021, 9, 171. [CrossRef]

28. WHO. Draft Landscape and Tracker of COVID-19 Candidate Vaccines. Available online: https://www.who.int/publications/m/ item/draft-landscape-of-covid-19-candidate-vaccines (accessed on 16 December 2021).

29. Gao, Q.; Bao, L.; Mao, H.; Wang, L.; Xu, K.; Yang, M.; Li, Y.; Zhu, L.; Wang, N.; Lv, Z.; et al. Development of an Inactivated Vaccine Candidate for SARS-CoV-2. Science 2020, 369, 77-81. [CrossRef]

30. Fadlyana, E.; Rusmil, K.; Tarigan, R.; Rahmadi, A.R.; Prodjosoewojo, S.; Sofiatin, Y.; Khrisna, C.V.; Sari, R.M.; Setyaningsih, L.; Surachman, F; et al. A phase III, observer-blind, randomized, placebo-controlled study of the efficacy, safety, and immunogenicity of SARS-CoV-2 inactivated vaccine in healthy adults aged 18-59 years: An interim analysis in Indonesia. Vaccine 2021, 39, 6520-6528. [CrossRef]

31. Kaur, S.P.; Gupta, V. COVID-19 Vaccine: A comprehensive status report. Virus Res. 2020, 288, 198114. [CrossRef]

32. FDA. Long Term Follow-Up After Administration of Human Gene Therapy Products, Guidance for Industry; FDA.gov: Silver Spring, MD, USA, 2020.

33. Dortant, P.; Claassen, I.; Van Kreyl, C.; Van Steenis, G.; Wester, P. Risk Assessment on the Carcinogenic Potential of Hybridoma Cell DNA: Implications for Residual Contaminating Cellular DNA in Biological Products. Biologicals 1997, 25, 381-390. [CrossRef]

34. Anderson, E.J.; Rouphael, N.G.; Widge, A.T.; Jackson, L.A.; Roberts, P.C.; Makhene, M.; Chappell, J.D.; Denison, M.R.; Stevens, L.J.; Pruijssers, A.J.; et al. Safety and Immunogenicity of SARS-CoV-2 mRNA-1273 Vaccine in Older Adults. N. Engl. J. Med. 2020, 383, 2427-2438. [CrossRef]

35. Jackson, L.A.; Anderson, E.J.; Rouphael, N.G.; Roberts, P.C.; Makhene, M.; Coler, R.N.; McCullough, M.P.; Chappell, J.D.; Denison, M.R.; Stevens, L.J.; et al. An mRNA Vaccine against SARS-CoV-2-Preliminary Report. N. Engl. J. Med. 2020, 383, $1920-1931$. [CrossRef]

36. Thomas, S.J.; Moreira, E.D., Jr.; Kitchin, N.; Absalon, J.; Gurtman, A.; Lockhart, S.; Perez, J.L.; Marc, G.P.; Polack, F.P.; Zerbini, C.; et al. Safety and Efficacy of the BNT162b2 mRNA Covid-19 Vaccine through 6 Months. N. Engl. J. Med. 2021, 385, 1761-1773. [CrossRef] [PubMed]

37. Cowling, B.J.; The University of Hong Kong. Third Dose of mRNA Vaccination to Boost COVID-19 Immunity. Available online: https:/ / clinicaltrials.gov/ct2/show/NCT05057182 (accessed on 16 December 2021).

38. Guanaccia, B.J.; Browne, F.; Yale-Griffin Prevention Research Cente. COVID-19 Booster Vaccination in Persons with Multiple Sclerosis. Available online: https:/ / clinicaltrials.gov/ct2/show/record/NCT05081271 (accessed on 16 December 2021).

39. Pfizer. Study to Evaluate the Safety and Efficacy of a Booster Dose of BNT162b2 Against COVID-19 in Participants $\geq 16$ Years of Age. Available online: https:/ / clinicaltrials.gov/ct2/show / NCT04955626?term=vaccine\&recrs=abdf\&cond=COVID-19\&phase= $012345 \&$ sort $=$ nwst\&draw $=2$ (accessed on 16 December 2021).

40. Heath, P.T.; Galiza, E.P.; Baxter, D.N.; Boffito, M.; Browne, D.; Burns, F.; Chadwick, D.R.; Clark, R.; Cosgrove, C.; Galloway, J.; et al. Safety and Efficacy of NVX-CoV2373 Covid-19 Vaccine. N. Engl. J. Med. 2021, 385, 1172-1183. [CrossRef]

41. Thanh Le, T.; Andreadakis, Z.; Kumar, A.; Gómez Román, R.; Tollefsen, S.; Saville, M.; Mayhew, S. The COVID-19 vaccine development landscape. Nat. Rev. Drug Discov. 2020, 19, 305-306. [CrossRef]

42. Voysey, M.; Clemens, S.A.C.; Madhi, S.A.; Weckx, L.Y.; Folegatti, P.M.; Aley, P.K.; Angus, B.; Baillie, V.L.; Barnabas, S.L.; Bhorat, Q.E.; et al. Safety and efficacy of the ChAdOx1 nCoV-19 vaccine (AZD1222) against SARS-CoV-2: An interim analysis of four randomised controlled trials in Brazil, South Africa, and the UK. Lancet 2021, 397, 99-111. [CrossRef]

43. Groves, D.C.; Rowland-Jones, S.L.; Angyal, A. The D614G mutations in the SARS-CoV-2 spike protein: Implications for viral infectivity, disease severity and vaccine design. Biochem. Biophys. Res. Commun. 2020, 538, 104-107. [CrossRef] [PubMed]

44. Korber, B.; Fischer, W.M.; Gnanakaran, S.; Yoon, H.; Theiler, J.; Abfalterer, W.; Hengartner, N.; Giorgi, E.E.; Bhattacharya, T.; Foley, B.; et al. Tracking Changes in SARS-CoV-2 Spike: Evidence that D614G Increases Infectivity of the COVID-19 Virus. Cell 2020, 182, 812-827.e19. [CrossRef]

45. Weissman, D.; Alameh, M.-G.; de Silva, T.; Collini, P.; Hornsby, H.; Brown, R.; LaBranche, C.C.; Edwards, R.J.; Sutherland, L.; Santra, S.; et al. D614G Spike Mutation Increases SARS CoV-2 Susceptibility to Neutralization. Cell Host Microbe 2021, $29,23-31 . e 4$. [CrossRef]

46. Collier, D.A.; De Marco, A.; Ferreira, I.A.T.M.; Meng, B.; Datir, R.P.; Walls, A.C.; Kemp, S.A.; Bassi, J.; Pinto, D.; Silacci-Fregni, C.; et al. Sensitivity of SARS-CoV-2 B.1.1.7 to mRNA vaccine-elicited antibodies. Nature 2021, 593, 136-141. [CrossRef] [PubMed]

47. Hoffmann, M.; Arora, P.; Grob, R.; Seidel, A.; Hörnich, B.F.; Hahn, A.S.; Krüger, N.; Graichen, L.; Hofmann-Winkler, H.; Kempf, A.; et al. SARS-CoV-2 variants B.1.351 and P.1 escape from neutralizing antibodies. Cell 2021, 184, 2384-2393.e12. [CrossRef] [PubMed]

48. Wang, P.; Casner, R.G.; Nair, M.S.; Wang, M.; Yu, J.; Cerutti, G.; Liu, L.; Kwong, P.D.; Huang, Y.; Shapiro, L.; et al. Increased resistance of SARS-CoV-2 variant P.1 to antibody neutralization. Cell Host Microbe 2021, 29, 747-751.e4. [CrossRef] 
49. Liu, C.; Ginn, H.M.; Dejnirattisai, W.; Supasa, P.; Wang, B.; Tuekprakhon, A.; Nutalai, R.; Zhou, D.; Mentzer, A.J.; Zhao, Y.; et al. Reduced neutralization of SARS-CoV-2 B.1.617 by vaccine and convalescent serum. Cell 2021, 184, 4220-4236.e13. [CrossRef]

50. Wall, E.C.; Wu, M.; Harvey, R.; Kelly, G.; Warchal, S.; Sawyer, C.; Daniels, R.; Hobson, P.; Hatipoglu, E.; Ngai, Y.; et al. Neutralising antibody activity against SARS-CoV-2 VOCs B.1.617.2 and B.1.351 by BNT162b2 vaccination. Lancet 2021, 397, $2331-2333$. [CrossRef]

51. Anonymous. Vaccinations in United Kingdom. Available online: https://coronavirus.data.gov.uk/details/vaccinations (accessed on 5 September 2021).

52. Elliot, P.; Haw, D.; Wang, H.; Eales, O.; Walters, C.E. REACT-1 Round 13 Final Report: Exponential Growth, High Prevalence of SARS-CoV-2 and Vaccine Effectiveness Associated with Delta Variant in England during May to July 2021. Available online: https:/ / spiral.imperial.ac.uk/handle/10044/1/90800 (accessed on 6 September 2021).

53. Flanagan, K.L.; MacIntyre, C.R.; McIntyre, P.B.; Nelson, M.R. SARS-CoV-2 Vaccines: Where Are We Now? J. Allergy Clin. Immunol. Pract. 2021, 9, 3535-3543. [CrossRef]

54. Cevik, M.; Grubaugh, N.D.; Iwasaki, A.; Openshaw, P. COVID-19 vaccines: Keeping pace with SARS-CoV-2 variants. Cell 2021, 184, 5077-5081. [CrossRef]

55. Abu-Raddad, L.J.; Chemaitelly, H.; Butt, A.A. Effectiveness of the BNT162b2 Covid-19 Vaccine against the B.1.1.7 and B.1.351 Variants. N. Engl. J. Med. 2021, 385, 187-189. [CrossRef]

56. Lopez Bernal, J.; Andrews, N.; Gower, C.; Gallagher, E.; Simmons, R.; Thelwall, S.; Stowe, J.; Tessier, E.; Groves, N.; Dabrera, G.; et al. Effectiveness of COVID-19 Vaccines against the B.1.617.2 (Delta) Variant. N. Engl. J. Med. 2021, 385, 585-594. [CrossRef] [PubMed]

57. Bueno, S.M.; Abarca, K.; González, P.A.; Gálvez, N.M.S.; Soto, J.A.; Duarte, L.F.; Schultz, B.M.; Pacheco, G.A.; González, L.A.; Vázquez, Y.; et al. Safety and Immunogenicity of an Inactivated Severe Acute Respiratory Syndrome Coronavirus 2 Vaccine in a Subgroup of Healthy Adults in Chile. Clin. Infect. Dis. 2021, ciab823. [CrossRef]

58. Tanriover, M.D.; Doğanay, H.L.; Akova, M.; Güner, H.R.; Azap, A.; Akhan, S.; Köse, Ş.; Erdinç, F.Ş.; Akalın, E.H.; Tabak, Ö.F.; et al. Efficacy and safety of an inactivated whole-virion SARS-CoV-2 vaccine (CoronaVac): Interim results of a double-blind, randomised, placebo-controlled, phase 3 trial in Turkey. Lancet 2021, 398, 213-222. [CrossRef]

59. Al Kaabi, N.; Zhang, Y.; Xia, S.; Yang, Y.; Al Qahtani, M.M.; Abdulrazzaq, N.; Al Nusair, M.; Hassany, M.; Jawad, J.S.; Abdalla, J.; et al. Effect of 2 Inactivated SARS-CoV-2 Vaccines on Symptomatic COVID-19 Infection in Adults. JAMA 2021, 326, 35-45. [CrossRef]

60. Polack, F.P.; Thomas, S.J.; Kitchin, N.; Absalon, J.; Gurtman, A.; Lockhart, S.; Perez, J.L.; Marc, G.P.; Moreira, E.D.; Zerbini, C.; et al. Safety and efficacy of the BNT162b2 mRNA COVID-19 vaccine. N. Engl. J. Med. 2020, 383, 2603-2615. [CrossRef] [PubMed]

61. Baden, L.R.; El Sahly, H.M.; Essink, B.; Kotloff, K.; Frey, S.; Novak, R.; Diemert, D.; Spector, S.A.; Rouphael, N.; Creech, C.B.; et al. Efficacy and Safety of the mRNA-1273 SARS-CoV-2 Vaccine. N. Engl. J. Med. 2021, 384, 403-416. [CrossRef] [PubMed]

62. Ramasamy, M.N.; Minassian, A.M.; Ewer, K.J.; Flaxman, A.L.; Folegatti, P.M.; Owens, D.R.; Voysey, M.; Aley, P.K.; Angus, B.; Babbage, G.; et al. Safety and immunogenicity of ChAdOx1 nCoV-19 vaccine administered in a prime-boost regimen in young and old adults (COV002): A single-blind, randomised, controlled, phase 2/3 trial. Lancet 2020, 396, 1979-1993. [CrossRef]

63. Madhi, S.A.; Baillie, V.; Cutland, C.L.; Voysey, M.; Koen, A.L.; Fairlie, L.; Padayachee, S.D.; Dheda, K.; Barnabas, S.L.; Bhorat, Q.E.; et al. Efficacy of the ChAdOx1 nCoV-19 Covid-19 Vaccine against the B.1.351 Variant. N. Engl. J. Med. 2021, 384, 1885-1898. [CrossRef] [PubMed]

64. Sadoff, J.; Gray, G.; Vandebosch, A.; Cárdenas, V.; Shukarev, G.; Grinsztejn, B.; Goepfert, P.A.; Truyers, C.; Fennema, H.; Spiessens, B.; et al. Safety and Efficacy of Single-Dose Ad26.COV2.S Vaccine against Covid-19. N. Engl. J. Med. 2021, 384, $2187-2201$. [CrossRef]

65. Logunov, D.Y.; Dolzhikova, I.V.; Shcheblyakov, D.V.; Tukhvatulin, A.I.; Zubkova, O.V.; Dzharullaeva, A.S.; Kovyrshina, A.V.; Lubenets, N.L.; Grousova, D.M.; Erokhova, A.S.; et al. Safety and efficacy of an rAd26 and rAd5 vector-based heterologous prime-boost COVID-19 vaccine: An interim analysis of a randomised controlled phase 3 trial in Russia. Lancet 2021, 397, 671-681. [CrossRef]

66. Faillie, J.-L.; Montastruc, F.; Montastruc, J.-L.; Pariente, A. Pharmacoepidemiology and its input to pharmacovigilance. Therapies 2016, 71, 211-216. [CrossRef]

67. AlOmar, M.; Tawfiq, A.; Hassan, N.; Palaian, S. Post marketing surveillance of suspected adverse drug reactions through spontaneous reporting: Current status, challenges and the future. Ther. Adv. Drug Saf. 2020, 11. [CrossRef]

68. Ibrahim, H.; Saad, A.; Abdo, A.; Eldin, A.S. Mining association patterns of drug-interactions using post marketing FDA's spontaneous reporting data. J. Biomed. Inform. 2016, 60, 294-308. [CrossRef] [PubMed]

69. Cai, R.; Liu, M.; Hu, Y.; Melton, B.L.; Matheny, M.; Xu, H.; Duan, L.; Waitman, L.R. Identification of adverse drug-drug interactions through causal association rule discovery from spontaneous adverse event reports. Artif. Intell. Med. 2017, 76, 7-15. [CrossRef]

70. Farcaş, A.; Măhălean, A.; Bulik, N.B.; Leucuta, D.; Mogoșan, C. New safety signals assessed by the Pharmacovigilance Risk Assessment Committee at EU level in 2014-2017. Expert Rev. Clin. Pharmacol. 2018, 11, 1045-1051. [CrossRef]

71. BPOM. Pengawalan Keamanan, Khasiat, dan Mutu Vaksin COVID-19. Available online: https://www.pom.go.id/new/view/ more/pers/572/Pengawalan-Keamanan--Khasiat--dan-Mutu-Vaksin-COVID-19.html (accessed on 6 September 2021).

72. Bahri, P.; Tsintis, P. Pharmacovigilance-related topics at the level of the International Conference on Harmonisation (ICH). Pharmacoepidemiol. Drug Saf. 2004, 14, 377-387. [CrossRef] [PubMed] 
73. WHO. What Is VigiBase? Available online: https://www.who-umc.org/vigibase/vigibase/ (accessed on 6 September 2021).

74. Ontario. COVID-19 Vaccine Surveillance Plan. Available online: https:/ / www.health.gov.on.ca/en/pro/programs/publichealth/ coronavirus/docs/vaccine/COVID-19_vaccine_surveillance_plan.pdf (accessed on 20 November 2021).

75. UK Health Security Agency. COVID-19 Vaccine Surveillance Report Week 42; UK Health Security Agency: London, UK, 2021.

76. England, P.H. COVID-19: Vaccine Surveillance Strategy. Available online: https://www.gov.uk/government/publications/ covid-19-vaccine-surveillance-strategy (accessed on 6 September 2021). 